\title{
Adaptive Capacity and Coping Strategies in the Face of Climate Change: A Comparative Study of Communities around Two Protected Areas in the Coastal Savanna and Transitional Zones of Ghana
}

\author{
Irene Susana Egyir ${ }^{1}$, Kwadwo Ofori $^{2}$, Godfred Antwi ${ }^{3} \&$ Yaa Ntiamoa-Baidu ${ }^{4}$ \\ ${ }^{1}$ Department of Agricultural Economics and Agribusiness, University of Ghana, Legon, Ghana \\ ${ }^{2}$ Department of Crop Science, University of Ghana, Legon, Ghana \\ ${ }^{3}$ Department of Agricultural Economics and Agribusiness, University of Ghana, Legon, Ghana \\ ${ }^{4}$ Department of Animal Biology and Conservation Sciences and Centre for African Wetlands, University of \\ Ghana, Legon, Ghana \\ Correspondence: Irene Susana Egyir, Department of Agricultural Economics and Agribusiness, University of \\ Ghana, Legon, Ghana. E-mail: ireneegyir@yahoo.com
}

\author{
Received: January 3, 2014 Accepted: February 27, 2014 Online Published: January 22, 2015 \\ doi:10.5539/jsd.v8n1p1 URL: http://dx.doi.org/10.5539/jsd.v8n1p1
}

\begin{abstract}
Modern productivity-enhancing strategies (MPES) are considered to be some of the best adaptation options available to communities in the face of changing climatic conditions. The adaptive capacity of communities living around two protected areas (Kogyae Strict Nature Reserve and Muni-Pomadze Ramsar Site) in Ghana were assessed in relation to MPES by investigating household accessibility to human, social, natural, financial and physical capital. Information was collected from 249 and 250 respondents in Kogyae and Muni respectively. A logit model was used to find out whether adaptive capacity affected adoption of MPES. In both study areas, indigenous coping strategies such as use of simple farm tools, processing of root/tubers and grains and social grouping were practiced. The MPES practiced included application of fertilizers and other agrochemicals, use of high technology machinery and bunding in rice fields. The mean level of adaptive capacity of farm households was low in both areas; 0.30 and 0.27 in Kogyae and Muni respectively. The adoption of MPES was influenced positively by the level of human and physical capacities and farm size and location of protected area, and negatively by farmers' participation in off-farm activities. Farmers located in Kogyae were more likely to adopt productivity-enhancing strategies than their counterparts in Muni. Considering that access to the resources within the protected areas is restricted and not legally available to support livelihoods of the fringe communities, we conclude that enhancing access to both human and physical capitals is the way forward for climate change adaptation for these two communities.
\end{abstract}

Keywords: farmer adaptive capacities, climate change, modern productivity-enhancing strategies, protected areas

\section{Introduction}

Climate change is arguably the most persistent threat to global environmental stability. Folland, Karl \& Salinger (2006) reported a warming of approximately $0.7^{\circ} \mathrm{C}$ over most of the African continent during the 20th century based on historical records. The fourth assessment report of the intergovernmental panel on climate change (IPCC) also reported that warming is very likely to be larger than the global annual mean warming throughout the continent and in all seasons, with drier subtropical regions warming more than the moister tropics (Christensen et al., 2007). In Ghana, using 1960 as baseline, the Environmental Protection Agency (EPA) concluded that temperatures in Ghana have increased by $1^{\circ} \mathrm{C}$ across the country (Agyeman-Bonsu et al., 2008), representing an average rate of $0.21^{\circ} \mathrm{C}$ per decade. Estimates by the Ghana Meteorological Agency (GMet) indicate that the situation could be worsened as rainfall is projected to decline by $2.2 \%, 8.8 \%$ and $14.6 \%$ by the years 2020, 2050 and 2080 respectively (Minia, 2004). Lacombe et al. (2012) and Owusu \& Waylen (2012) provided evidence that communities in the transition and coastal savannah zones of Ghana are experiencing climatic changes with both the major and minor raining seasons getting shorter and the length of the growing season decreasing, resulting in reduced ability of farmers to crop more than once in a year in most places. 
The economies of developing countries are mainly based on agriculture that is mostly subsistence in nature, with a high dependence on rainfall for irrigation. As a result, agriculture in these countries is highly vulnerable to changes in climate variability, seasonal shifts, and precipitation patterns (WRI, 1996). The overdependence of agricultural households in developing countries on nature means that such households are more likely to bear the impacts of climate change through changes in natural resources availability, ecosystems, water cycles and, food systems and the need to cope with a changing regime of weather extremes (Owusu \& Waylen, 2012). Africa's inhabitants are reported to have developed highly effective strategies to cope with drought since the region became semi-arid some four or five thousand years ago (Andah, 1993; Casey, 1998). However, the continent is characterized by a low adaptive capacity and a large proportion of rural people continue to depend on natural resources for subsistence, which in turn contributes to further land degradation and desertification. The low adaptive capacity has been attributed also to the deteriorating ecological base, widespread poverty, inequitable land distribution, and devastating effects of HIV/AIDS (Hulme, 1996; IPCC, 1998; Magadza, 2003; Ikeme, 2003).

In order to reduce the deteriorating ecological base several economies have ceded off areas in forested and wetlands zones as nature reserves and ramsar sites (Attuquayefio \& Fobil, 2005; Salm et al., 2002; Lindenmayer \& Franklin, 2002). Some of the nature reserves are strictly unavailable while others can be used with permission only. This situation exposes agricultural systems within the latter zone to high risk, especially when there are no proper structures and processes for intervening. Chambers \& Conway (1991) explain that agricultural households that are placed in such a vulnerability context remain incapacitated, slow to respond to the shocks and unfavourable trends. In Ghana, the situation described can be identified with crop farming communities in the fringes of the Kogyae Strict Nature Reserve and the Muni Ramsar sites. The Kogyae Strict Nature Reserve, the only strict nature reserve in Ghana, was established in 1971 (Ghana Legislative Instrument 710). The reserve is situated near Ejura within the forest-savannah transition zone and covers ca. $386 \mathrm{sq}$. km. According to the management plan of the reserve, the objectives for the establishment of the Kogyae Strict Nature Reserve include retaining the transitional vegetation and faunal types for scientific research and monitoring; serving as benchmark for monitoring the southwards advancement of the Guinea savannah; and protecting the watersheds of the tributaries of Sene and Afram Rivers (Wildlife Division, 2002). The Muni-Pomadze site which is situated near Winneba in the Central Region of Ghana was designated as a Ramsar site in 1992 on the basis of its importance for water birds (Ntiamoa-Baidu et al., 2000). The site covers ca. 9500 ha and is the catchment of three seasonal streams (Gordon et al., 2000). With access to such a wide area of local biological diversity, ecosystem services and cultural landscape farmers could explore other food systems (Nyong et al., 2007; Gyampoh et al., 2007). In Ghana for example, farmers engage in the hunting of wild animals for food as well as collection of nuts, fruits and spices for home consumption and/or for sale when allowed into reserves (Gyampoh et al., 2007; Ntiamoa-Baidu, 1997).

It remains unclear the structures put in place to support farming households who hitherto sought alternative livelihoods in the Kogyae and Muni areas. Structures that will allow farm households to maintain surpluses from crop harvest are the preferred choice of farm households who are less skilled to consider other ventures. If agricultural households do not get surpluses from food crop harvests, they cannot participate in markets, earn income and buy more food, clothing, medicare and facilities for general wellbeing. They become less empowered and therefore more vulnerable to climate change. However, Paavola (2008) has observed that households that depend upon agriculture for livelihoods have sought to escape the vulnerability cycle by adopting a diversification strategy. If they cannot seek alternative livelihoods in resource rich areas of the communities in which they live (taking advantage of ecosystems services), they migrate to seek greener pastures elsewhere or adopt intensification options. The intensification options selected are both indigenous and modern. The indigenous knowledge and practices, including planting mixtures of crops and crop cultivars are handed over to them by relatives or developed through personal experiences to reduce vulnerability. Indigenous knowledge is gained through the tested experiences and observations of local people and offer useful trends about changing trends and patterns of the seasons and weather (Codjoe, Owusu \& Burkett, 2014). Farming communities also adopt scientific methods or modern technology introduced to them by different stakeholders, including agricultural extension, forestry, conservation and environmental protection services (Adjei-Nsiah \& Kemah, 2012). The use of modern technology to improve agricultural systems in production and distribution of crops, livestock and fisheries has been reported to be good practice and key adaptation strategy to climate change (Huq et al., 2004). The modern technologies may be mechanical, biological, chemical or managerial in nature and they are productivity enhancing in that they improve crop yields or livestock numbers and make access to markets easier. In the long run they increase household income and thereby reduce poverty. 
Adger et al. (2003) explained that innovativeness is a last resort for adaptation. Innovation in agriculture includes conventional agricultural-related coping measures which is dependent on capacity of households to adopt the measures. It means that, when extensive agricultural measures that exploit the "bush farming system" are no longer an option, some capacities of households will need to be strengthened in order to gain more from the limited land available. This study therefore asks: how are households coping with climate variability since they lost the opportunity offered by the Kogyae and Muni? Specifically, what human and non-human capital have been relevant to household adaptation to climate change crop production? The major objective of this study is to assess the relationship between climate change adaptation measures and adaptive capacity (in terms of the five capital) of farm households around the two protected areas. The specific objectives are to describe the situation of indigenous and modern coping strategies adopted by farmers, measure the level of farmers' capacity (human, natural, physical, financial and social capital level) and determine the extent to which farm household capacity influence adoption of climate change coping strategies, termed modern productivity enhancing strategies (MPES).

The purpose of this research is to make a case for communities around forest and wetland protected areas. There is no doubt about capacity strengthening of all households that are vulnerable to changing climatic factors. However, those around protected areas are restricted in their benefit of ecosystem services. It is important that policy makers, especially those at the local level, know and understand the pressing capacity needs and which group among the households to target. A number of studies across Africa have shown that the determinants of farmers' choice of adaptation methods to climate change are related to the five capitals, viz., natural, human, financial, physical and social (Deressa et al., 2009; Yaro, 2006 and 2004; Davis, 1996). Access to natural capital allows farmers to engage in shifting cultivation, bush farming and collection of non-timber forest products (Boon \& Ahenkan, 2011). Adequate human capital allows households to explore alternatives based on new information and innovativeness (Alsos et al., 2003; Adger et al., 2003). Access to financial capital enables farmers to purchase productivity enhancing inputs or diversify into off-farm manufacturing and trading (Mamoudu et al., 2011; Beg et al., 2000). Access to physical infrastructure enhances socio-economic status by making people mobile and be able to migrate or take advantage of facilities for watering, storage and processing of agricultural products (Ishaya and Abaje, 2008). Social capital enhances collective action and use of group advantage to access the other capitals (Sadick et al., 2013; Stanturf et al., 2011). What is missing in the empirical literature is the case of protected areas which this paper contributes. The study's diagnoses of farm households that live by rich resources that has restricted entry is interesting. We suggest that legislation is not enough; how government and the NGOs partner to support households around protected areas to comply is important.

\section{Brief Literature Review}

\subsection{Impact of Climate Change on Agriculture}

Agriculture in Africa has been described as highly vulnerable to changes in climate variability, seasonal shifts, and precipitation patterns (WRI, 1996). The FAO (1999) identified general impacts of climate change on agriculture as reduction in soil fertility, decreased livestock productivity directly (through higher temperatures) and indirectly (through changes in the availability of feed and fodder), increased incidence of pest attacks, resulting from increase in temperature, the manifestation of vector and vector borne diseases, and negative impacts on human health affecting human resource availability. The decrease in yield that results from these conditions has been analysed. In Ghana, Arnell et al. (2002) observed that, even with a stabilisation of $\mathrm{CO}_{2}$, maize yields will still decrease by 2.5 to 5 percent by the 2080s. Owusu \& Waylen (2012) observed that rainfall in both Ejura and Wenchi (transition zone) has seen a reduction in both the major and minor rainy seasons and an infilling during the short dry spell resulting in a high risk of crop failure during the minor rainy season as the onset of the rain delays and early termination occurs. Along the coast, marine resources dependent and inland communities have been studied. Acquah \& Onumah (2011) observed that in Dunkwa (Shama Ahanta East District) farmers perceived climate change as persistent drought and used a mixture of crop varieties to cope with the challenge.

\subsection{Coping Strategies and Climate Change}

The reality of climate change has been seen in the new positions and actions individuals, households, nations or the world at large have taken when there is drought or flood or extremes of climate factors. The response has been described as adaptation or coping strategies. Whether people adapt or cope has been differentiated by some schools and used interchangeably by others. FAO for instance observed that lessons on agricultural household climate change adaptation span from short term coping measures such as reducing the number of daily meal times, through migration, to adaptation strategies such as adopting productivity-enhancing measures (FAO, 
2005). Smit et al. (2000) see adaptation simply as a response to concerns about climate change. They assert that adaptation depends fundamentally on the characteristics of the system of interest including its sensitivities and vulnerabilities. Vulnerability means not lack or want but defenselessness (Chambers, 1989). It includes insecurity, exposure to risk, shocks and stress; exposure to contingencies and difficulties in coping with them. The nature of adaptation process and forms can be distinguished by attributes such as timing, purposefulness and effect. Adaptation to climate change has been viewed by others as a long term phenomenon in that when farmers using traditional techniques of agricultural production notice that the climate has altered, they need time to identify potentially useful adaptations, learn, organize resource and implement them (Maddison, 2006; Smit \& Wandel, 2006). The resources include those from farmer' own sources and those external to them; the latter include policy making and scientific knowledge systems (Yaro, 2013). Scientific knowledge systems encompass the use of new varieties of crops and breeds of animals, integrated pest management principles, integrated soil fertility management principles and forestry management. Both coping and adaptation strategies concern diversification and specialization which have been observed as farm level response to climate change (Bradshaw et al., 2004).

\subsection{Adaptive Capacity and Climate Change}

While accepting that the impact of climate change is widespread and farmers' perception is not unclear, some studies have observed that some farmers who have observed climate change fail to respond (Maddison, 2006; Davis, 1996). Maddison (ibid.) listed inability to borrow, lack of appropriate seed, security of land tenure or market accessibility as barriers. He further observed that although it is the experienced farmer who perceives climate change, it is mostly the educated farmer that responds. The implication is that the capacity to adapt is variable. Adaptive capacity here refers to "the ability of a (human) system to adjust to climate change (including climate variability and extremes), to moderate potential damages, to take advantage of opportunities, or to cope with the consequences" (FAO, 2008). Low adaptive capacity has been attributed to deteriorating ecological base, widespread poverty, inequitable land distribution, a high dependence on the natural resource base and the ravages of HIV/AIDS (Hulme, 1996; IPCC, 1998; Magadza, 2003; Ikeme, 2003). Access, status, and ability are key factors in adaptive capacity. Marginal groups include those with few resources and little access to power, which can constrain people's capacity to adapt to climate changes that could have a negative impact on them. It is usually people's few productive assets that are at greatest risk from the impacts of climate change. Physical assets can be damaged or destroyed, financial losses can be incurred, natural assets can be degraded and social assets can be undermined. Improving adaptive capacity is important in order to reduce vulnerability to climate change (Bradshaw et al., 2004).

Denton et al. (2001) observed that much has been invested in Africa in terms of capacity building, but more is needed to enhance the adaptive capacity of institutions, organizations and individuals. Several elements of adaptive capacity noted as essential include education, access to resources and infrastructure, wealth, better forecasting and linking research to policy (ILRI, 2006; Huq \& Reid, 2006; Sewell \& Smith, 2004). Which of these should be the focus for individual household adaptation? Differences in location are also likely to influence the extent to which these elements affect adoption of planned or modern adaptation measures. The current study seeks to use two protected areas in the forest and coastal savanna zones of Ghana to identify which elements of adaptive capacity are most essential for farmer households and that needs enhancement. In other words what are the factors of adaptation strategy choice?

\section{Method}

\subsection{Conceptual Explanations}

The central theme of this study was coping/adaptation strategy choice due to rainfall variability and extreme weather conditions. The complexity of climate change leads to a consideration of three aspects of the decision theory: (1) Decisions under certainty: where a manager has far too much information to choose the best alternative. (2) Decisions under conflict: where a manager has to anticipate moves and counter-moves of one or more competitors. (3) Decisions under uncertainty: where a manager has to dig-up a lot of data to make sense of what is going on and what it is leading to. Choice guided by utility is clear in this situation (Green 2008) and binary choice models including the probit and logit models can be used to identify determinants of choice. Individual choices impact how climate policy should be framed (Green 2008). Farmers are assumed to be rational and as such when a "hazard" is identified, they would assess the potential adverse impacts and take measures to reduce the risk or adverse consequences. Boon \& Ahenkan (2011) observed that responses of households to a state of the environment include changes in management strategies. In this study, the measures taken by farmers in order to cope with rainfall variability and extreme weather conditions were either the status quo (indigenous practices) or innovation (the modern productivity-enhancing strategies (MPES)). The 
observation was that due to unpredictable rainfall patterns, farmers could no longer depend on rain water alone, stick to one cropping calendar, use local seeds, use one type of implement for land preparation and ignore improved soil and water conservation practices. Hence, some crop farmers will use agrochemicals and inorganic fertiliser, high-tech machinery for ploughing and irrigation and improved variety of seed or planting materials. High-tech machinery includes tractors for ploughing and harrowing and pumping machines for lifting water onto fields. Bunding as a land management strategy is peculiar to rice production. In this study about 58 percent of respondents used MPES whiles 42 percent did not used it. Since some (albeit small percentage) of the farmers stuck to the status quo, we assumed that those who adopted the MPES had peculiar characteristics. Personal characteristics such as age and gender, and access to assets (financial, human, natural, physical and social) were explored.

\subsection{Data Collection Methods: Sample Size and Sampling Procedure}

The data were collected through questionnaire surveys from 499 household members in the selected farming communities in the fringes of Kogyae (249) and Muni (250) protected areas. By definition, Kogyae is strictly protected with all use prohibited apart from use for scientific studies. As a Ramsar site, Muni is expected to be managed under the principle of multiple-use, which implies that other uses compatible with the objective of designation of the site may be allowed. The farming communities studied in the Kogyae area included Asubuoso, Bilina No.1, Congo, Dome, Konja, Kyekyebon, Oku and Sasebonso, while those in the Muni area included Ablekum, Awonberew, Akosua villiage, Bewadze, Gomoa Amenfi, Onyinadze and Otsew Darkwa. They had experienced rainfall variability and extreme weather conditions. The total sample of 499 was deemed adequate for generalization of responses and a good statistical number for logit estimation. Sixteen farming communities in each area were identified by the District Agricultural Development Units of the local governments (Sekyere Central and Effutu districts) who are mandated to provide extension services at the municipal areas.

The eight communities in Kogyae and seven in Muni were randomly selected using balloting. Fifty percent of households in each community were targeted for interviews since the normality of the population size had not been determined (Rea \& Parker, 2005). About 94 percent of the target was achieved. The participants were any adult who owned a food crop or cash crop farm or contributed to decision on input procurement and was willing to be a respondent without monetary motivation. About 90 percent of the sample approached participated. Ten percent of participants selected themselves. Four graduate students were trained to participate in the face-to-face interviewing of respondents. Two researchers facilitated three focus group discussions with community leadership groups as well as carried out 10 key informant interviews with local public and private institutions in each protected area. The focus group discussions and observations allowed the researchers to understand (1) lifestyle of different categories of persons in the communities: children, young and unmarried men, young and unmarried women, older women and men, migrants, indigenes; (2) Land tenure system and challenges; (3) food diversity, availability and household consumption patterns; (4) trends in migration; and (5) support provided by local institutions to farming households.

\subsection{Data Analyses Methods}

The strategies that farmers inherited as "practices of our fathers" were described as "indigenous" while those introduced by the Ministry of Food and Agriculture or other formal organisations such as research institutes, local government and NGOs were described as "modern and productivity-enhancing". These strategies were chosen in order to cope with rainfall variability and extreme weather conditions. At both Kogyae and Muni, the MPES considered for crop production were pesticides, fertiliser, tractor, pumping machine, improved variety of seed and a land management method (bunding) peculiar to rice production in Muni. Any respondent whose household used one or a combination of the MPES was scored 1 and respondents who used none of these were scored 0 . About 73 percent of respondents in Muni and 89 percent in Kogyae used the MPES respectively.

The elements of farmers' adaptive capacity were first categorized into the five capitals: human, natural, physical, financial and social. For each category, critical elements were identified and scored, 1 for Yes and 0 for No. The scores were based on attributes such as threshold numbers, status, access, ability and participation/association. An average score of 0.5 for each capital was considered as adequate. The overall Adaptive Capacity (AC) was obtained by dividing the total score of the attributes for the $i$ th respondent by the sum of most desirable score of all attributes, thereby reducing the adaptive capacity to a scale of $0 \leq \mathrm{AC} \leq 1$ (Asante et al., 2013). It has been suggested that any index of $0<\mathrm{AC}<0.33$ should be considered as low, $0.33<\mathrm{AC}<0.5$, as moderate and $\mathrm{AC} \geq 0.5$, as high (Asante et al., 2013).

A logit model was used to find out whether adaptive capacity affected adoption of MPES based on the equation,

$$
\text { Prob MPES }=\beta_{o}+\beta_{i} X_{i}+e
$$


where the $\beta$ 's are parameters and X's are the determinants of MPES (Oparinde and Hodge, 2011) and i is from 1 to $\mathrm{n}(\mathrm{n}=13)$. The determinants selected included gender, age, off-farm income, total farm income, farm size, origin of farmer, wealth status of farmer, level of the five capitals and location/type of protected area (Table 1). Farmers were either located in the Kogyae strict nature reserve or Muni, with limited restriction. Farmers who have off farm income may earn wages, trade or engage in processing. Farmers' origin is explained as indigenes or migrants; the former are likely to be land owners. In the survey, the wealthy households were identified with those who lived in their own houses; the houses were made of cement walls, aluminum roofs and cement floors. Majority of them owned motor cycles, bicycles, furniture, canoes/boats, mobile phones and durable utensils and clothing with high salvage value. These assets can be liquidated and ploughed into agriculture (purchase MPES) when the need arises. The selection of the variables was based on both differences shown with descriptive statistics as well as suggestions from the adoption literature. It is suggested that certain socio-demographic (personal/community), technical (cost of technology) and institutional (access to markets) factors are key in determining the direction of technology adoption (Adesina \& Baidu-Forson, 1995). The analysis was done using STATA software (version 11). The marginal effects were determined to show the extent to which significant variables influence adoption of MPES.

Table 1. Description of variables

\begin{tabular}{|c|c|c|c|c|c|}
\hline \multirow[t]{2}{*}{ Variables } & \multirow[t]{2}{*}{ Measurement } & \multicolumn{2}{|c|}{ Innovation } & \multirow{2}{*}{$\begin{array}{l}\text { Mean } \\
\text { Difference }\end{array}$} & \multirow[t]{2}{*}{ T test } \\
\hline & & Used & Not used & & \\
\hline Location & $\begin{array}{l}\text { Location of respondent } \\
1=\text { farmer located in Kogyae } \\
0=\text { Farmer located in Muni }\end{array}$ & 0.7600 & 0.1300 & -0.631 & $-17.770 * * *$ \\
\hline Age & Age of respondent (Years) & 44.2457 & 43.3476 & 0.898 & $0.648^{*}$ \\
\hline Gender & $\begin{array}{l}\text { Sex of the respondent } \\
1=\text { Male } \\
0=\text { Female }\end{array}$ & 0.6125 & 0.5905 & 0.495 & 0.022 \\
\hline $\begin{array}{l}\text { Total farm } \\
\text { income }\end{array}$ & $\begin{array}{l}\text { Total household income in a year } \\
\text { (GHS) }\end{array}$ & 1216.42 & 2449.293 & -1222.05 & $-1969 * * *$ \\
\hline Wealth status & $\begin{array}{l}\text { Wealth of farmer shown by type of } \\
\text { roofing material } \\
1=\text { Aluminum, } 0=\text { otherwise }\end{array}$ & 0.3391 & 0.5905 & -0.251 & $-5.749 * * *$ \\
\hline Origin & $\begin{array}{l}\text { Residential status of respondent } \\
1=\text { Indigene } \\
0=\text { Migrant }\end{array}$ & 1.7855 & 1.4762 & 7.563 & $0.309 * * *$ \\
\hline $\begin{array}{l}\text { Off farm } \\
\text { income }\end{array}$ & $\begin{array}{l}\text { Farmer engaged in off-farm work } \\
1=\text { Engaged } \\
0=\text { Otherwise }\end{array}$ & 0.5467 & 0.6762 & -0.129 & $-2.935 * * *$ \\
\hline Farm size & $\begin{array}{l}\text { Land area under cultivation } \\
\text { (Hectares) }\end{array}$ & 0.3806 & 0.0429 & 0.338 & $9.479 * * *$ \\
\hline Social capital & Mean index of four factors & 0.1066 & .02190 & 0.085 & $7.623 * * *$ \\
\hline $\begin{array}{l}\text { Natural } \\
\text { Capital }\end{array}$ & Index of two factors & 0.3253 & 0.3690 & -0.049 & $-1.631 * *$ \\
\hline $\begin{array}{l}\text { Physical } \\
\text { resource }\end{array}$ & Index of seven factors & 0.5913 & 0.5144 & 0.077 & $5.947 * * *$ \\
\hline $\begin{array}{l}\text { Financial } \\
\text { capital }\end{array}$ & Index of five factors & 0.1121 & 0.0695 & 0.043 & $3.572 * * *$ \\
\hline Human capital & Index of four factors & 0.3348 & 0.2464 & 0.088 & $4.953 * * *$ \\
\hline
\end{tabular}




\section{Results}

The specific objectives of the study were to describe the situation of indigenous and modern strategies adopted by farmers to cope with rainfall variability and extreme weather; measure the level of farmers' capacity (human, natural, physical, financial and social capital level) and determine the extent to which farm household capacity influenced adoption of climate change coping strategies, termed modern productivity enhancing strategies (MPES).

\subsection{The Indigenous and Modern Coping Strategies Adopted by Farmers}

The three most important indigenous strategies that were reported by respondents were simple tools, agro processing and identifying with clan members (social grouping) (Figure 1). Others engaged in informal micro savings known as susu, providing drainage on farm fields, and at Kogyae, engaging in "bucket irrigation" or hand watering of vegetable gardens during the dry season. The major modern strategies that farmers used to cope in both areas were agrochemicals, improved seed, modern irrigation and high tech machinery and at Muni, also bunding of rice fields (Figure 2).

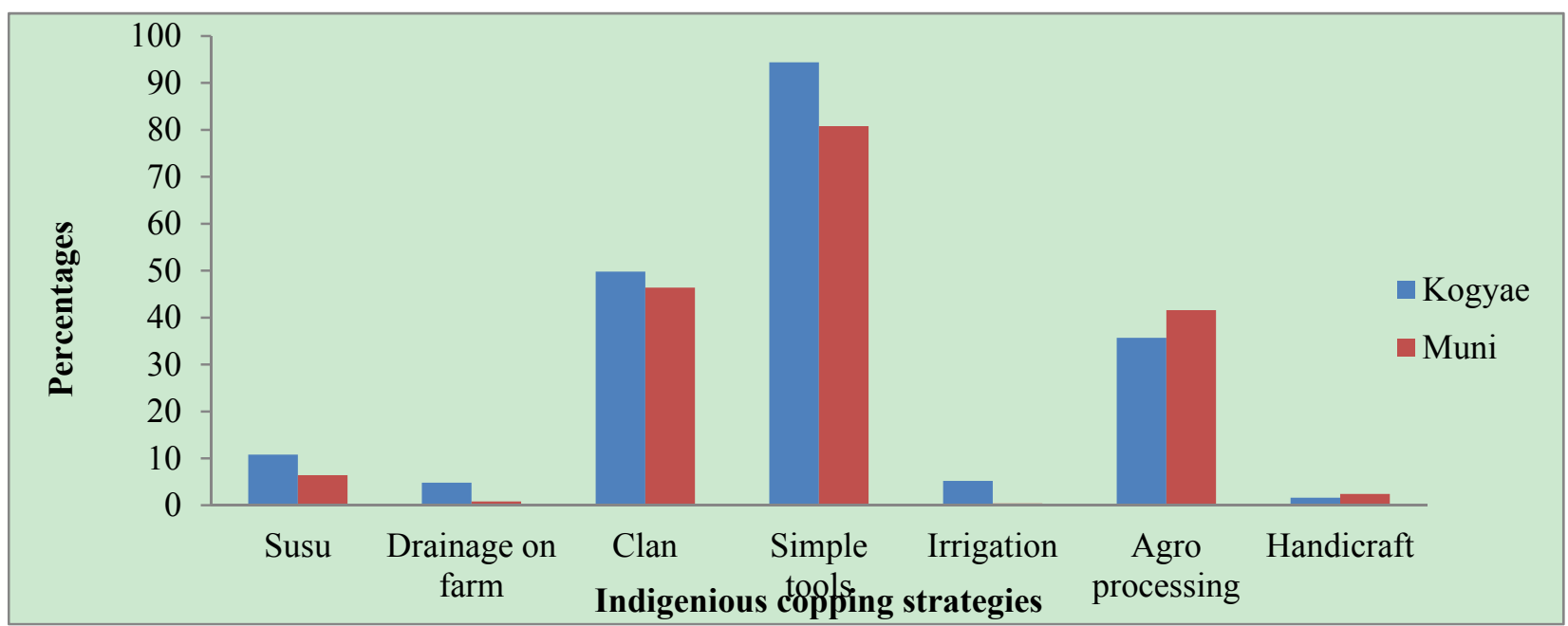

Figure 1. Types of indigenous coping strategies reported by farm households in the study areas

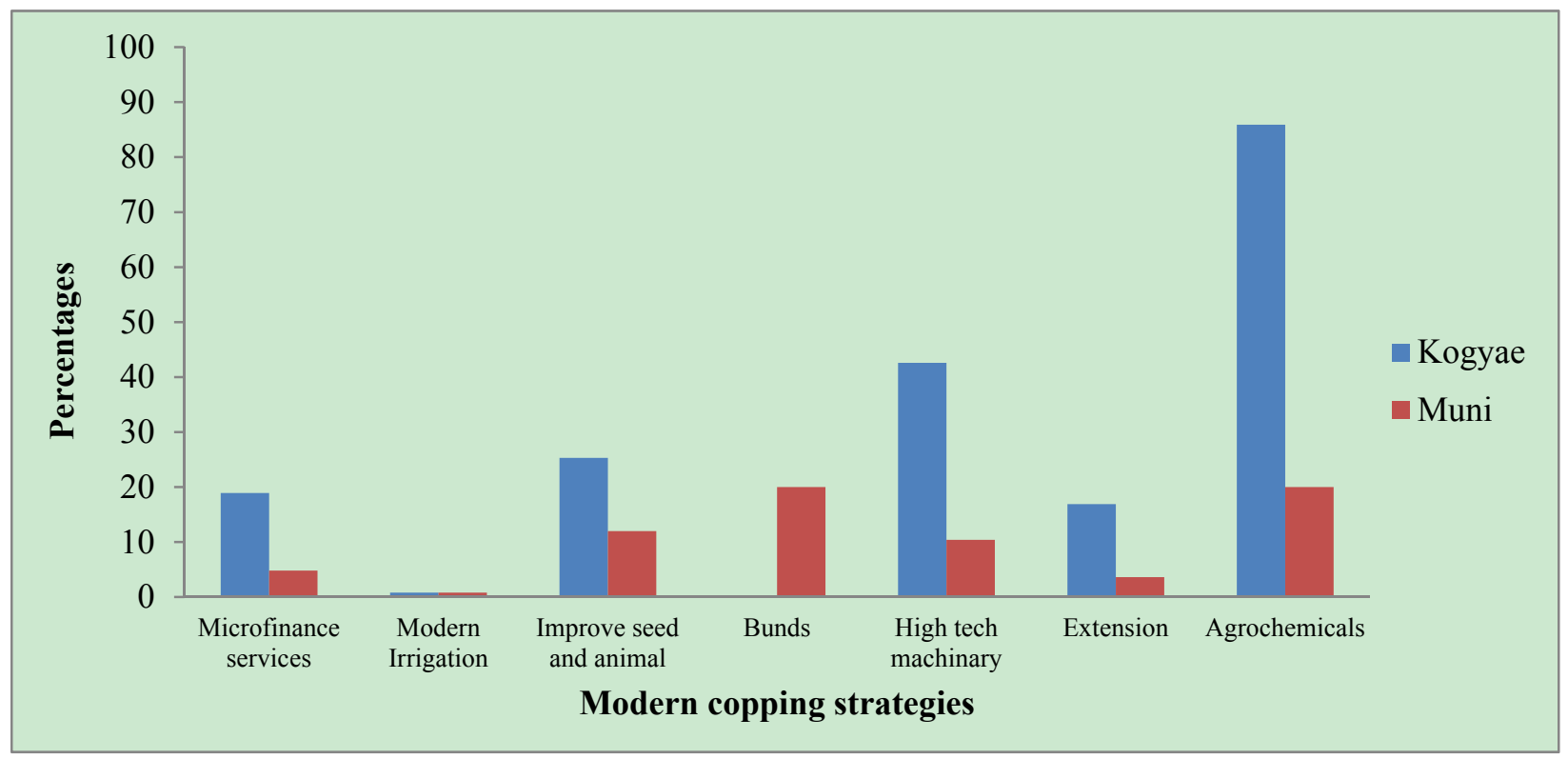

Figure 2. Types of modern coping strategies reported by farm households in the study areas 
4.2 Level of Farmers' Capacity: The Situation of Human, Physical, Financial, Social and Natural Capital of Farm Households in Two Protected Areas in Ghana

The overall mean score of adaptive capacity level was 0.30 . The mean score for Muni was 0.25 and that for Kogyae was 0.29 . As shown in Table 2, in terms of the five capitals, there were significant differences between Kogyae and Muni. The least capacity score of 0.005 was associated with social capital at Muni, while the highest of 0.58 was associated with physical capital at Kogyae. Apart from physical capital, all the other capitals scored lower than the 0.50 expected.

Social capital: The socio-economic networking capacity of farmers in both areas was weak (Table 3). None of the respondents associated with research and training institutions in any of the two areas and no farmer participated in farmer-based organization (FBO) or community based organisation (CBO) activities in Muni. Participation in community clan activities was moderate in both areas.

Financial capital: The ability of farmers to save and obtain adequate and long term credit from informal and formal sources was low (Table 4). None of the respondents in the two areas had ever obtained credit of more than one year term. More farmers at Kogyae than Muni saved and obtained credit from informal sources. Slightly more farmers in Muni than Kogyae obtained credit from formal sources but the difference was not statistically significant.

Natural capital: Farmers' access to natural capital was low in both areas as expected. However, more farmers in Kogyae (90.4\%) than Muni (40.8\%) admitted that they exploited natural resources from the reserves. The difference in the situation was significant at 1 percent level $(\mathrm{T}$-value $=32.737)$.

Human capital: In terms of experience in farming and literacy, farmers in Muni were better than those in Kogyae., More farmers at Kogyae had access to business information than at Muni (Table 5). Although not statistically significant, there were slightly more farmers in Kogyae than in Muni who had members of their households working outside the community.

Table 2. Differences in five capitals level in Kogyae and Muni areas

\begin{tabular}{llllll}
\hline Variables & Measurement & $\begin{array}{l}\text { Area } \\
\text { Kogyae }\end{array}$ & Muni & Mean Difference & T test \\
\hline Social capital & Index of six factors & 0.139 & 0.005 & 0.134 & $13.766^{* * *}$ \\
Natural Capital & Index of two factors & 0.3123 & 0.374 & -0.062 & $-2.297^{* *}$ \\
Physical resource & Index of seven factors & 0.579 & 0.538 & 0.041 & $3.123^{* * *}$ \\
Financial capital & Index of six factors & 0.111 & 0.078 & 0.033 & $2.810^{* * *}$ \\
Human capital & Index of four factors & 0.325 & 0.270 & 0.055 & $3.095^{* * *}$ \\
Total Adaptive Capital & & 0.294 & 0.253 & 0.041 & $5.269^{* * *}$ \\
\hline
\end{tabular}

$*=10 \% ; * *=5 \%$ and $* * *=1 \%$ significant levels

Table 3. Social capital situation of households in the study area

\begin{tabular}{|c|c|c|c|c|}
\hline \multirow[t]{2}{*}{ Capital elements } & \multicolumn{2}{|c|}{ Percent response } & \multirow[t]{2}{*}{ T-value } & \multirow[t]{2}{*}{$\mathrm{P}>[\mathrm{Z}]$ value } \\
\hline & Kogyae & Muni & & \\
\hline Participated in $\mathrm{FBO} / \mathrm{CBO}$ & 0.4 & 0.0 & -1.004 & 0.316 \\
\hline Associated with formal educational institutions & 2.8 & 0.8 & -1.689 & 0.092 \\
\hline Associated with formal research and training institutions & 0.0 & 0.0 & 0.0000 & - \\
\hline Associated with formal NGOs & 21.7 & 8.0 & -4.375 & 0.000 \\
\hline Associated with formal governmental organisations & 16.5 & 8.8 & -2.59 & 0.010 \\
\hline Participate in Clan activities & 49.8 & 46.4 & 0.756 & 0.488 \\
\hline
\end{tabular}


Table 4. Financial capital situation of households in study area

\begin{tabular}{lllll}
\hline Capital elements & \multicolumn{2}{l}{ Percent response } & T-value & P $>[Z]$ value \\
\cline { 2 - 3 } & Kogyae & Muni & -2.734 & 0.006 \\
\hline Able to save & 30.1 & 19.6 & -3.233 & 0.001 \\
$\begin{array}{l}\text { Able to obtain } \\
\text { informal credit }\end{array}$ & 22.9 & 12.0 & 0.914 & 0.372 \\
$\begin{array}{l}\text { Able to obtain formal } \\
\text { credit }\end{array}$ & 2.9 & 4.4 & & \\
$\begin{array}{l}\text { Able to obtain large } \\
\text { capital (>GHS 1000) }\end{array}$ & 0.0 & 0.8 & 1.414 & 1.158 \\
$\begin{array}{l}\text { Able to obtain long } \\
\text { term capital }(>12\end{array}$ & 0.0 & 0.0 & & - \\
months) & & & & \\
\hline
\end{tabular}

Physical capital: In general, more farmers in Muni than Kogyae had easy access to socio-economic infrastructure. However, with respect to land for farming, more farmers in Kogyae than Muni possessed land sizes of 2 hectares or greater. More farmers in Kogyae than Muni had access to market storage facilities (Table 6). The facilities that were most difficult to access in Kogyae were markets, good roads and transportation. The facilities that were most difficult to access in Muni were farm land and markets.

\subsection{The Effect of Adaptive Capacity on Adoption of Modern Coping Strategies to Climate Change}

The pseudo R-squared of the logit model was significant at 1 percent level, indicating that the model was adequate (Table 7). There are five significant variables, viz., location, off-farm, farm size and human and physical capitals. The magnitudes of the marginal effects on significant variables ranged from 11 to 69 percent. The strength of relationship between capacity and adoption was fairly high at $1 \%-5 \%$.

Table 5. Human resource capacity situation of households in study area

\begin{tabular}{|c|c|c|c|c|}
\hline \multirow[t]{2}{*}{ Capital elements } & \multicolumn{2}{|c|}{ Percent response } & \multirow[t]{2}{*}{ T-value } & \multirow[t]{2}{*}{$\mathrm{P}>[\mathrm{Z}]$ value } \\
\hline & Kogyae & Muni & & \\
\hline Farming for 10 years or more & 26.5 & 61.2 & 0.044 & 0.003 \\
\hline Literate (received more than 6 years of formal education) & 45.8 & 54.8 & 2.947 & 0.000 \\
\hline Have access to business information & 20.1 & 9.2 & -3.473 & 0.001 \\
\hline Household member work outside community & 20.9 & 16.0 & -1.406 & 0.160 \\
\hline
\end{tabular}

Table 6. Physical capital situation of households in study area

\begin{tabular}{|c|c|c|c|c|}
\hline \multirow[t]{2}{*}{ Capital elements } & \multicolumn{2}{|c|}{ Percent response } & \multirow[t]{2}{*}{ T-test } & \multirow[t]{2}{*}{$\mathrm{P}>[\mathrm{Z}]$ value } \\
\hline & Kogyae & Muni & & \\
\hline Have access to good road infrastructure & 13.7 & 100.0 & 8.885 & 0.000 \\
\hline Have access to markets within 30 mins. & 2.0 & 39.3 & 19.391 & 0.000 \\
\hline Have access to regular transportation within 30 mins. & 37.8 & 74.4 & 13.895 & 0.000 \\
\hline Have access to processing facility & 98.8 & 98.1 & 4.705 & 0.000 \\
\hline Have access to market storage facilities & 94.4 & 69.2 & -7.688 & 0.000 \\
\hline Have access to portable water & 63.9 & 84.8 & 13.895 & 0.397 \\
\hline Have access to farm size of 2 ha and above & 43.0 & 4.8 & -11.167 & 0.000 \\
\hline
\end{tabular}




\section{Discussion}

Farmers' indigenous practices persist because of the perceived low risk associated with them. Many of the simple tools used were manufactured by farmers themselves to till the land, raise livestock or capture fish. At Muni, farmers practice agro-processing of fish (fried or smoked) and cassava (processed into gari) for immediate sale or storage, while at Kogyae agro-processing were identified with cassava, groundnut and seeds of wild fruits. Agro-processing has been identified as a key traditional strategy in climate change adaptation in other countries (Orindi et al., 2005).

Planting of vegetable crops such as tomatoes and onions using nearby rivers for irrigation against risks associated with droughts is a common practice among farmers in the Transition Zone (also observed by Yaro et al., 2010). Susu is a traditional way of encouraging micro savings and credit; members of a group rotate the accumulated funds as credit or receive funds for working capital at the end of an agreed period, say one month. In this way household are able to wait for the next harvest and there is consumption smoothening.

The major modern coping strategies of farmers in both areas were the use of agrochemicals and high tech machinery. Agrochemicals used included pesticides such as weedicides and insecticides. The pesticides control weeds and insects rapidly and help farmers to manage new and unknown pests that are emerging due to climate change. Fertilisers improve soil nutrients faster than organic manures; hence farmers who do not have new fields available for shifting cultivation depend on it. The leading agrochemical used in both study areas was the weedicide which allowed farmers to clear lands quickly and manage weeds promptly for improved yields. The use of high-tech machinery and improved seed (planting materials) were also important. In maize farming systems in both areas, farmers' use of the improved seed variety such as obatanpa was common. In cassava farming systems the new improved variety was tech bankye. Such varieties have shorter gestation periods and are drought resistant. Boon \& Ahenkan (2011) also found in their study in the Sefwi area of Ghana, that an important agricultural coping strategy was the promotion and cultivation of crops such as hybrids of cocoa, cassava and maize that had shorter gestation periods and were drought resistant. High-tech machinery was mainly tractor for ploughing and harrowing, and pumping machines for lifting dam water unto fields. We note that the modern technologies are both land and labour saving and when they are encouraged, shifting cultivation and extensive farming will not be needed by small holder farmers in communities around the two protected areas.

Table 7. Logit results of factors that influence adoption of modern coping strategies to climate change

\begin{tabular}{lllll}
\hline Variables & Coefficients & Standard error & $\mathrm{P}>|\mathrm{z}|$ & Marginal effect \\
\hline Location & $2.9017^{* * *}$ & 0.400 & 0.000 & 0.5860 \\
Off-farm & $-0.5077^{* * *}$ & 0.262 & 0.055 & -0.1137 \\
Farm size & $0.8947^{* *}$ & 0.452 & 0.048 & 0.1870 \\
Gender & 0.2993 & 0.322 & 0.353 & - \\
Age & -0.0145 & 0.009 & 0.106 & - \\
Total farm income & -0.0001 & 0.000 & 0.353 & - \\
Origin & 0.0703 & 0.289 & 0.807 & - \\
Wealth status & 0.3051 & 0.291 & 0.294 & 0.6960 \\
Physical capacity & $3.0459^{* * *}$ & 1.017 & 0.003 & 0.4409 \\
Human capacity & $1.9300^{* * *}$ & 0.681 & 0.005 & - \\
Financial capacity & 1.4623 & 0.962 & 0.129 & - \\
Natural capacity & -0.0440 & 0.434 & 0.919 & - \\
Social capacity & 0.3056 & 1.465 & 0.835 & $=$ \\
Constant & -2.8573 & 0.837 & 0.001 & $=$ \\
Number of observations & & & & 0.3861 \\
Waldchi ${ }^{2}(13)$ & & & & 262.23 \\
Prob>chi & & & & $0.0000^{* * *}$ \\
PseudoR & & & & \\
\hline & & & & \\
\end{tabular}


The MPES such as irrigation and high-tech enabled modification of planting dates and cropping more than once a year, while agrochemicals afforded better protection and management of both field and stored products.

The results showed that adaptive capacity level varied for farm households in the Kogyae and Muni areas, but on the whole were inadequate (score of 0.31 ). The inadequate adaptive capacity was accounted for mainly by the low level of social, financial, natural and human capitals. That low social capital could be attributed to minimum socio-economic networking through formal association with farmer-based or community-based organizations, non-governmental organizations, research organizations or government institutions. Cultural heritage, sustained through clan activities was found to be diminishing since less than 50 percent of respondents in both communities were engaged actively in such activities. In the past, rural households depended mostly on cultural heritage and association with neighbours to improve access to goods and services and assets (World Bank, 2003). In the districts where the protected areas were located, as in every district in Ghana, there were government departments (cooperatives, agriculture and community development agencies) that were mandated to link farmers to markets and provide them with information to improve their bargaining power. There were also rural enterprise projects that offered business advice. Agricultural Extension Agents (AEA) were assigned to every community, although it is observed that national Agricultural Extension Agent (AEA) to farmer ratio was 1:3000. The rapid penetration of mobile telephony has potential to improve linkage of farmers to holders of technical information (including AEAs). These connections, however, were yet to be fully explored by farm households in the study areas.

The low financial capital could be attributed to the low income level, low savings culture and difficulty in obtaining adequate and long term credit from both informal and formal sources. During community walk and interaction with key informants in both the Kogyae and Muni areas, it was discovered that there were many financial institutions in the district capitals - rural banks, savings and loans companies, micro-finance companies and branches of major banks such as the Ghana Commercial Bank and Agricultural Development Bank. However, majority of the households said they did not have the ability to save on their own or with the financial institutions, because they did not earn enough and their little income was ploughed back into business or spent on household welfare items such as food, child education, medical care and social events. Access to credit was precluded by the high interest rates and collateral requirements of institutions, which confirms the findings of Ehigiamusoe (2008) in Nigeria. Majority of household members in the study areas could not negotiate for credit beyond 12 months, or funds beyond GHф1000.00 (USD500.00) per annum. According to Akudugu et al. (2009), poor financial capital status is the bane of most households in developing countries.

As would be expected for communities living within and around protected areas where access to resources is restricted, the degree of adaptive capacity with respect to natural capital was low. It was interesting to note that in Kogyae which is a Strict Nature Reserve, many households admitted that they visited the forest occasionally to harvest different non-timber species such as snail, mushrooms and wild seeds and fruits. "If we cannot use the forest as grazing land, or obtain extra land for crop field expansion, we should be allowed to collect non-wood species", as one respondent said. Use of ecosystem service as a strategy for coping with climate change challenges is widespread in tropical Africa (Nyong et al., 2007).

With respect to human capital, although most of the farmers had long experience in farming, the literacy rate was low and they had inadequate access to business information. Literacy unlocks and reduces ignorance; it provides potential for exploring a wide range of occupation both within and outside one's community and it improves employability skills. Thus, improving the situation of human capital in the two areas would need to target education of farmers.

In terms of physical capital, farmers in the two communities had fair access to physical infrastructure such as good roads, readily accessible markets, transport vehicles, as well as processing and storage facilities and potable water. Majority of the households especially at Kogyae, spent over thirty minutes to access facilities such as good roads, transport vehicles and retail markets. The situation does not deviate much from what was reported in the 2003 core welfare indicators questionnaire (CWIQ) for the two districts where the study was carried out (GSS, 2005). Poor access to infrastructure leads to limitation in movement; many households cultivate small farm sizes (less than 2 hectares) in their immediate vicinity. Over 50 percent of the households in the two areas focused on food crops - roots and tubers, cereals, legumes and vegetables. Cultivation of tree crops such as oil palm, cocoa, coconut and citrus was limited by land availability and although keeping of livestock offered a viable alternative the farmers kept only small numbers of pigs, sheep, goats and poultry (fowls and guinea fowls), using semi-intensive methods. The reason for this was that the cost of well-designed housing, planned feeding, watering and provision of medication for animals was considered too high for the resource poor farmers. 
The indications from the logit results were that, index of human and physical capitals, location of farmer, farm size and off-farm occupation all influenced the adoption of modern coping strategies. The results showed that if human capital were to be developed it would enhance adoption of MPES by at least 44 percent. Bocker (1993) observed that provision of training, especially through formal schooling, eventually improves one's capacity to obtain information. The information is then used for effective on-farm decisions including exploring innovative options such as the modern coping strategies to climate change.

The probability that a household with easy access to physical infrastructure will adopt productivity enhancing techniques in the face of climate change was 69 percent. Indeed, when inputs are available even at a distant place, good roads provide easy access; when yields improve, easy access to markets will sustain farmers' interest. As noted by Akudugu et al. (2012) income for farmers in developing countries depends mostly on the capacity to sell surplus production.

The marginal effect on farm size was about 19 percent. This implies that as the area under cultivation is increased by one hectare there is approximately 19 percent probability that a household will adopt new technology in the face of climate change. In other words, households that have larger farm sizes were more likely to adopt MPES. Such households can engage in mixed cropping, food crops, tree crops and other cash crops and so can experiment and adopt the MPES. Households with larger farms are also the wealthier households that can afford to purchase the required inputs. The implication is that for small households to adopt MPES external support will be necessary.

There was 11 percent probability that a household member who did not engage in off-farm activities (or is a full-time farmer) will adopt improved farm practices that are productivity enhancing. Such a person uses farming as major income source and is likely to want to improve harvest situation all the time. The influence of age on adoption was weak but it appeared that younger farmers were more likely to adopt MPES than older farmers. Financial capital was not significant but had the a priori expected sign; the importance of equity and debt financing in agribusiness cannot be overemphasized- money is needed to purchase the improved inputs. Social capital was not significant but appeared to be important. Natural capital was not significant and as expected it appeared that access to it was likely to reduce the probability of adoption. Indeed, we observe from the results that, farmers in Kogyae who were restricted to natural resource use were more likely (probability of approximately $59 \%$ ) to use MPES.

In general, this study has shown that for communities living around protected areas, high capital, especially related to human resource is needed by households to enhance adoption of productivity enhancing inputs that are needed to ensure increased food production in the face of climate change. Hence, education and information seeking ability of household members need to be targeted during programme development by both governmental and non-governmental stakeholders.

\section{Conclusions and Recommendations}

This study explored the coping/adaptive strategies adopted by households in communities around the Kogyae Strict Nature Reserve and the Muni-Pomadze Ramsar sites in Ghana, considering the changing climatic conditions (rainfall and temperature) and the loss of free access to the wildlife resources with the establishment of the protected areas. The study showed that baring slight differences in the two areas, as the adaptive capacity of households increased the adoption of modern coping strategies also increased. The most important capitals that contribute to adaptive capacity and showed significant influence on adoption of modern coping strategies were human and physical capital. This highlights the need for some policy interventions, key among which would be:

1) The Local Government of the two areas taking the necessary steps to improve infrastructure such as roads and market stores, which is the physical capital, in order to enhance access to improved and productivity enhancing inputs by farm households,

2) Encouraging farm households in the two areas to prioritise formal schooling and information seeking abilities in order to make informed choices. Therefore interventions to strengthen the ability of households in these areas should center on education to improve the human capital. The priority target for such education programmes should be the younger farmers and the programme should include campaigns that advocate for use of modern strategies that would help them to cope in the face of climate change.

3) Government to support private sector to invest in agricultural service provision and input trading and establishing outlets close to farmers, especially in protected areas such as Kogyae that are strict nature reserve. 


\section{Acknowledgements}

This study was undertaken under the project Building Capacity to meet the Climate Change Challenge (B4C)-Ghana, which is implemented by a consortium of three institutions led by the University of Ghana and includes the Centre for African Wetlands and the Ghana Wildife Society. We are grateful for the funding from the Open Society Foundation under its African Climate Change Adaptation Initiative (ACCAI) programme. We acknowledge also the help of officers of Sekyere-Central, Ejura-Sekyedumase, Effutu and Gomoa East and West districts of Ghana during the field data collection.

\section{References}

Acquah, H. D., \& Onumah, E. E. (2011). Farmers Perception and Adaptation to Climate Change: An Estimation of Willingness to Pay. Agris on-line Papers in Economics and Informatics, 3(4), 31-39.

Adesina, A. A., \& Baidu-Forson, J. (1995). Farmers' perceptions and adoption of new agricultural technology: evidence from analysis in Burkina Faso and Guinea, West Africa. Agricultural Economics, 13(1), 1-9. http://dx.doi.org/10.1016/0169-5150(95)01142-8

Adger, W. N., Huq, S., Brown, K., Conway, D., \& Hulme, M. (2003). Adaptation to climate change in the developing world. Progress in Development Studies, 3(3), 179-195. http://dx.doi.org/10.1191/1464993403ps060oa

Adjei-Nsiah, S., \& Kemah, M. (2012). Climate change and shifts in cropping system: from cocoa to maize based cropping system in Wenchi area of Ghana. British Journal of Environment and Climate Change, 2(2), 137-152.

Agyemang-Bonsu, W. K., Minia, Z., Dontwi, J., Dontwi, I. K., Buabeng, S. N., Baffoe-Bonnie, B., ... Frimpong, E. B. (2008). Ghana climate change impacts, vulnerability and adaptation assessments. Accra, Ghana. NCAP study.

Andah, B. (1993). Identifying early farming traditions of West Africa. In T. Shaw, P. Sinclair, B. Andah, \& A. Okpoko (Eds.), The Archaeology of Africa: Food, Metals and Towns (pp. 240-254). London, UK: Routledge.

Akudugu, M. A., Dittoh, S., \& Mahama, E. S. (2012). The Implications of Climate Change on Food Security and Rural Livelihoods: Experiences from Northern Ghana. Journal of Environment and Earth Science, 2(3), 21-29.

Akudugu, M., Egyir, I. S., \& Mensah-Bonsu, A. (2009). Women farmers' access to credit from rural banks in Ghana. Agricultural Finance Review, 69(3), 284-299.

Alsos, G. A., Ljunggren, E., \& Pettersen, L. T. (2003). Farm-based entrepreneurs: what triggers the start-up of new business activities? Journal of Small Business and Enterprise Development, 10(4), 435-443. http://dx.doi.org/10.1108/14626000310504747

Asante, F. A., Boakye, A. A., Egyir, I. S., \& Jatoe, J. B. D. (2012). Climate change and farmers' adaptive capacity to strategic innovations: The case of northern Ghana. International Journal of Development and Sustainability, 1(3), 59-69. Retrieved from http://isdsnet.com/ijds-v1n3-11.pdf

Beg, N. M., Davidson, O. J. C., Afrane-Okesse, Y., Tyani, L., Denton, F., Sokona, Y., Thomas, J. P., La Rovere, E. L., \& Parikh, J. K. (2002). Linkages between climate change and sustainable development. Climate Policy, 2, 129-144. http://dx.doi.org/10.3763/cpol.2002.0216

Bocker, A. (1993). Migration and social security. The case of Turkish migrants in The Netherlands and their relatives at home. Journal of Legal Pluralism and Unofficial Law, 25(33), 13-31. http://dx.doi.org/10.1080/07329113.1993.10756440

Boon, E., \& Ahenkan, A. (2011). Assessing Climate Change Impacts on Ecosystem Services and Livelihoods in Ghana: Case Study of Communities around Sui Forest Reserve. $J$ Ecosyst Ecogr, S3:001. http://dx.doi.org/10.4172/2157-7625.S3-001

Bradshaw, B., Dolan, H., \& Smit, B. (2004). Farm-level adaptation to climate variability and change: crop diversification in the Canadian prairies. Climate Change, 67(1), 119-141.

Casey, T. M. (1998). Assessment of a seasonal forecast model. Aust Meteorol Mag, 47(2), 103-113.

Chambers, R. (1989). Editorial introduction: Vulnerability, coping and policies. Institute of Development Studies IDS Bulletin, 20(2), 1-7. http://dx.doi.org/10.1111/j.1759-5436.1989.mp20002001.x

Chambers, R., \& Conway, G. (1992). Sustainable rural livelihoods: practical concepts for $21^{\text {st }}$ century. IDS 
Discussion Paper 296, Institute of Development Studies, University of Sussex, Brighton, UK.

Christensen, J. H., Hewitson, B., Busuioc, A., Chen, A., Gao, X., Held, I., ... Wheton, P. (2007). Climate Change 2007: the physical science basis. Contribution to working group I to the fourth assessment report of the intergovernmental panel on climate change (pp. 847-940). Cambridge University Press, Cambridge.

Codjoe, S. N. A., Owusu, G., \& Burkett, V. (2014). Perception, experiences and indigenous knowledge of climate change and variability: The case of Accra, a sub-Saharan African city. Reg Environ Change, 4(1), 369-383. http://dx.doi.org/10.100.10007/s10113-013-0500-0

Codjoe, S. N. A., \& Owusu, G. (2011). Climate change/variability and food systems: evidence from the Afram Plains, Ghana. Reg Environ Change, 11(4), 753-765. http://dx.doi.org/10.1007/s10113-011-0211-3

Codjoe, S. N. A., Atidoh, L. K., \& Burkett. V. (2011). Gender and occupational perspectives on adaptation to climate extremes in the Afram Plains of Ghana. Climate Change, 110, 431-454.

Davis, S. (1996). Adaptable livelihoods: Coping with food insecurity in the Malian Sahel. MacMillan Press Ltd., London.

Deressa, T. T., Hassan, R. M., Ringler, C., Alemu, T., \& Yesuf, M. (2009). Determinants of farmers' choice of adaptation methods to climate change in the Nile Basin of Ethiopia. Global Environmental Change, 19(2), 248-255. http://dx.doi.org/10.1016/j.gloenvcha.2009.01.002

Ehigiamusoe, G. (2008). The Role of Microfinance Institutions in the Economic Development of Nigeria. Central Bank of Nigeria, 32(1), 17-25.

Folland, C. K., Karl, T. R., \& Salinger, M. J. (2006). Observed climate variability and change. Weather, 57(8), 269-278. http://dx.doi.org/10.1256/004316502320517353

Food and Agriculture Organisation (FAO). (2005). Fisheries and aquaculture topics. The sustainable livelihoods approach. Topic fact sheets. Text by Benoit Horemans. In FAO Fisheries and Aquaculture Department. Rome. Retrieved from http//www.fao.org/fishery/topic/14837/en

Ghana Statistical Service (GSS). (2005). Core welfare indicators questionnaire (CWIQ). Accra. Ghana: Ghana Statistical Service.

Gordon, C., Ntiamoa-Baidu, Y., \& Ryan, M. (2000). The Muni-Pomadze-Ramsar site. Biodiversity and Conservation, 9, 446-464.

Green, A. (2008). Self control, individual choice and climate change. Virgina Environmental Law Journal, 26, 77-106.

Gyampoh, B. A., Amisha, S., Idinoba M., \& Nkem J. (2009). Using traditional knowledge to cope with climate change in rural Ghana. Unasylva, 231/232(60), 70-74.

Hulme, M., Doherty, R., Ngara, T., News, M., \& Lister, D. (2001). African climate change: 1900-2100. Climate Research, 17(1), 145-168. http://dx.doi.org/10.3354/cr017145

Hulme, P. E. (1996). Herbivory, plant regeneration and species coexistence. Journal of Ecology, 84(4), 609-615. http://dx.doi.org/10.2307/2261482

Huq, S., Reid, H., Konate, M., Rahman, A., Sokona, Y., \& Crick, F. (2004). Mainstreaming adaptation to climate change in Least Developed Countries (LDCs). Climate Policy, 4(1), 25-43. http://dx.doi.org/10.1080/14693062.2004.9685508

Ikeme, J. (2003) Climate change adaptational deficiencies in developing countries: the case of Sub-Saharan Africa. Mitigation and Adaptation Strategies for Global Change, 8, 29-52. http://dx.doi.org/10.1023/A:1025838610473

Lacombe, G., McCartney M., \& Forkuor G. (2012). Drying climate in Ghana over the period 1960-2005: evidence from the resampling-based Mann-Kendall test at local and regional levels. Hydrological Sciences Journal, 57(8), 1594-1609.

Madison, D. (2006). The perception of and adaptation to climate change in Africa. CEEPA Discussion Paper No. 10. Centre for Environmental Economics and Policy in Africa. University of Pretoria, Pretoria.

Magadza, C. (2003). Engaging Africa in adaptation to climate change. In J. B. Smith, R. J. T. Klein, \& S. Huq (Eds.), Climate change: Adaptive capacity and development. London. Imperial College Press.

Minia, Z. (2004). Climate Scenarios Developed for Climate Change Impact Assessment in Ghana. The 
Netherlands Climate Change Studies Assistance Programme (NCCSAP). Phase 2-Part, 1.

Ntiamoa-Baidu, Y. (1997). Wildlife and food security in Africa. FAO Conservation Guide, No. 33, FAO, Rome.

Ntiamoa-Baidu, Y., Nyame, S. K., \& Nuoh, A. A. (2000). Trends in the use of a small coastal lagoon by waterbirds: Muni Lagoon in Ghana. Biodiversity and Conservation, 9(4), 527-539. http://dx.doi.org/10.1023/A:1008959915039

Nyong, A., Adesina, F. \& Elasha, B. O. (2007). The value of indigenous knowledge in climate change mitigation and adaptation strategies in the African Sahel. Mitigation and Adaptation Strategies for Global Climate Change, 12(5), 787-797. http://dx.doi.org/10.1007/s11027-007-9099-0

Oparinde, A., \& Hodge, I. (2011). Building livelihood resilience: a case study of factors affecting farm households' adoption of coping and adaptive strategies in rural Nigeria. MPRA Paper 39162, University Library of Munich, Germany.

Orindi, V. A., \& Murray, L. A. (2005). Adapting to climate change in East Africa: A strategic approach. London. International Institute for Environment and Development (IIED).

Owusu, K., \& Waylen, P. R. (2012). The Changing Rainy Season Climatology of mid-Ghana. Theoretical and Applied Climatology. http://dx.doi.org/10.1007/s00704-012-0736-5

Paavola, J. (2008). Livelihoods, vulnerability and adaptation to climate change in Morogoro, Tanzania. Environmental Science and Policy, 11, 642-654. http://dx.doi.org/10.1016/j.envsci.2008.06.002

Rea, L. M., \& Parker, R. A. (2005). Designing and conducting survey research. A comprehensive guide (3rd ed.). San Fransisco. Jose Bass Publishers.

Smit, B., Burton, I, Klein, R. J. T., \& Wandel, J. (2000). An anatomy of adaptation to climate change and variability. Climate Change, 45(1), 223-251.

Smit B., \& Wandel, J. (2006). Adaptation, adaptive capacity and vulnerability. Global Environment Change, 16(3), 282-292. http://dx.doi.org/10.1016/j.gloenvcha.2006.03.008

Stanturf, J. A., Melvin, L. W. Jr., Susan, C., Sophia, C. P., Scott, L. G., Frederick, A., \& Yaw, A. N. (2011). Ghana climate change vulnerability and adaptation assessment. United State International Development Programme.

Watson, R. T., Zinyowera, M. C., \& Moss, R. H. (Eds.). (1998). The regional impacts of climate change: an assessment of vulnerability. Cambridge University Press.

Wildlife Division. (2002). An action plan for biodiversity conservation and sustainable livelihoods in the "Special Use Zone", Kogyae Strict Nature Reserve. Wildlife Division of the Forestry Commission, Ghana. Unpublished report.

World Bank. (2003). A users' guide to poverty and social impact assessment. Washington, D.C. USA. The World Bank Poverty Reduction Group (PRMPR) and Social Development Department (SDV). The International Bank for Reconstruction and Development.

World Resources Institute. (1996). World resources: A guide to global environment, 1996-1997. United Nations Environment Program, World Bank, Oxford University Press.

Yaro, J. A. (2004). Theorising food insecurity: building a livelihood vulnerability framework for researching food insecurity. Norsk Geografisk-Norwegian Journal of Geography, 58, 23-37. http://dx.doi.org/10.1080/00291950410004375

Yaro, J. A. (2006). Is deagrarianisation real? A study of livelihood activities in rural northern Ghana. The Journal of Modern African Studies, 44(1), 125-156. http://dx.doi.org/ 10.1017/S0022278X05001448

Yaro J. A. (2013). The perception of and adaptation to climate variability/change in Ghana by small scale and commercial farmers. Reg Environ Change, 13(6), 1259-1272. http://dx.doi.org/ 10.10007/s10113-0130443-5

\section{Copyrights}

Copyright for this article is retained by the author(s), with first publication rights granted to the journal.

This is an open-access article distributed under the terms and conditions of the Creative Commons Attribution license (http://creativecommons.org/licenses/by/3.0/). 